\title{
ANALISIS PENGARUH KARAKTERISTIK PERJALANAN BELANJA TERHADAP PILIHAN LOKASI BELANJA KEBUTUHAN SEHARI-HARI DI JABODETABEK
}

\author{
Pamela Anggita $^{1}$ dan Leksmono Suryo Putranto ${ }^{2}$ \\ ${ }^{1}$ Program Studi Sarjana Teknik Sipil, Universitas Tarumanagara, Jl. Letjen S. Parman No.1 Jakarta \\ Email: anggitapml@gmail.com \\ ${ }^{2}$ Program Studi Sarjana Teknik Sipil, Universitas Tarumanagara, Jl. Letjen S. Parman No.1 Jakarta \\ Email: lexy_putranto@yahoo.co.id
}

\begin{abstract}
ABSTRAK
Transportasi terjadi karena adanya keharusan manusia untuk memenuhi kebutuhannya yang tidak dapat dipenuhi ditempatnya saat itu berada. Kegiatan berbelanja kebutuhan sehari-hari merupakan salah satu aktivitas pemenuhan kebutuhan yang dilakukan secara rutin. Tanpa disadari perjalanan belanja merupakan salah satu variabel penting yang berpotensi untuk meningkatkan jumlah perjalanan lalu lintas. Wilayah jabodetabek merupakan kawasan dengan perkembangan penduduk dan teknologi terpesat di Indonesia. Perkembangan teknologi baru dan tren konsumsi memiliki dampak penting terhadap perilaku perjalanan belanja. Karakteristik perjalanan belanja dibagi menjadi dua bagian yaitu karakteristik belanja dan karakteristik toko penyedia kebutuhan. Penelitian ini dilakukan untuk mengetahui variabel yang paling mempengaruhi perjalanan belanja. Penelitian ini dilakukan dengan menggunakan alat ukur kuesioner yang disebarkan secara langsung dan secara online. Didapatkan sebanyak lima puluh enam responden untuk kuesioner langsung dan enam puluh sembilan responden untuk kuesioner online. Data dianalisis menggunakan one sample t-test dan korelasi pearson untuk mengetahui seberapa besar pengaruh faktor-faktor yang diduga mempengaruhi pilihan lokasi belanja kebutuhan sehari-hari dan latar belakang responden terhadap pilihan lokasi belanja. Berdasarkan hasil penelitian, jenis produk belanja memiliki pengaruh paling besar dalam pemilihan lokasi belanja kebutuhan sehari-hari. Jika dibandingkan dengan responden pria, hal tersebut paling berpengaruh kepada responden wanita.
\end{abstract}

Kata kunci: pilihan lokasi belanja, perjalanan belanja, karakteristik belanja, karakteristik toko.

\section{PENDAHULUAN}

\section{Latar Belakang}

Transportasi terjadi karena adanya keharusan manusia untuk memenuhi kebutuhannya. Salah satu aktivitas pemenuhan kebutuhan yang dilakukan oleh manusia secara rutin adalah berbelanja kebutuhan sehari-hari. Berbeda dari perjalanan untuk memenuhi kebutuhan akan pendidikan dan pekerjaan yang dilakukan secara monoton, tidak semua manusia melakukan perjalanan berbelanja kebutuhan sehari-hari secara teratur dan terencana seperti halnya perjalanan untuk bekerja. Setiap individu memiliki kebiasaan ataupun pertimbangan yang berbeda-beda saat melakukan perjalanan belanja.

Salah satu wilayah atau kawasan dengan perkembangan penduduk dan teknologi terpesat di Indonesia adalah Jabodetabek. Jabodetabek merupakan salah satu wilayah yang memiliki rasio tingkat kepadatan kendaraan tertinggi di Indonesia. Perubahan yang berkaitan dengan perkembangan teknologi baru dan tren konsumsi memiliki dampak penting terhadap perilaku belanja, yang mempengaruhi tingkah laku perjalanan yang berbeda, termasuk karakteristik perjalanan belanja (Routhier dkk, 2009 pada SUN dkk, 2017). Menurut Gonzales-Feliu dkk (2010), meskipun kontribusi pergerakan konsumen dengan kendaraan bermotor dalam alur perjalanan kota merupakan hal yang penting, hal tersebut jarang diperhitungkan dalam tata logistik kota, baik dalam pembuatan peraturan serta perencanaan dan perbaikan sistem transportasi kota.

Penelitian mengenai alasan individu melakukan pergerakan atau perjalanan ke suatu tata guna lahan dapat mempermudah perencanaan sistem transportasi pada wilayah penelitian tersebut dilakukan. Dengan memahami bagaimana karakteristik perjalanan belanja individu mempengaruhi pilihan lokasi toko penyedia kebutuhan seharihari, perencanaan sistem transportasi terpadu di sekitar wilayah lokasi toko dapat dilaksanakan lebih baik. 


\section{Batasan Masalah}

1. Wilayah yang digunakan dalam penelitian ini adalah JABODETABEK (Jakarta, Bogor, Depok, Tangerang, dan Bekasi).

2. Subjek penelitian merupakan individu utama dalam rumah tangganya yang melakukan aktivitas belanja kebutuhan sehari-hari.

3. Subjek penelitian merupakan individu yang bertanggung jawab dalam menyediakan kebutuhan sehari-hari rumah tangganya.

4. Subjek penelitian merupakan pemegang kekuasaan atas budgeting dan penentu aktivitas belanja kebutuhan sehari-hari, maka ART (Asisten Rumah Tangga) tidak dapat dianggap sebagai subjek penelitian.

5. Teman belanja yang dimaksud dalam penelitian ini adalah individu yang menemani subjek penelitian dalam melakukan aktivitas belanja. Teman belanja dapat berupa teman kantor, teman sebaya maupun keluarga.

6. Anggota rumah tangga yang dimaksud dalam penelitian ini adalah individu yang tinggal dalam satu rumah dan tanggung jawab pemenuhan kebutuhan sehari-harinya berada dibawah naungan subjek penelitian.

\section{Rumusan Masalah}

1. Bagaimana karakteristik belanja mempengaruhi pilihan lokasi belanja kebutuhan sehari-hari?

2. Bagaimana karakteristik toko mempengaruhi pilihan lokasi belanja kebutuhan sehari-hari?

3. Variabel apa yang berperan paling penting dalam pilihan lokasi belanja kebutuhan sehari-hari?

\section{Tujuan Penelitian}

1. Mengetahui pengaruh karakteristik belanja terhadap pilihan lokasi belanja kebutuhan sehari-hari.

2. Mengetahui pengaruh karakteristik toko terhadap pilihan lokasi belanja kebutuhan sehari-hari.

3. Mengetahui variabel yang berperan paling penting terhadap pilihan lokasi belanja kebutuhan sehari-hari.

\section{TINJAUAN PUSTAKA}

\section{Karakteristik Perjalanan Belanja}

Menurut KBBI, karakteristik adalah kondisi dimana sesuatu atau seseorang mempunyai sifat khas sesuai dengan perwatakan tertentu. Karakteristik perjalanan belanja dapat diartikan sebagai sifat atau jati diri seseorang dalam melakukan perjalanan untuk belanja dalam rangka memenuhi kebutuhan sehari-hari.

Menurut Guy dan Wrigley (1981) memberikan empat pendekatan untuk memprediksi tingkah laku perjalanan belanja: berdasarkan meminimalkan usaha (terdekat lebih disukai); berdasarkan penampilan yang diberikan (yang paling disukai); berdasarkan pilihan yang berbeda (adanya proses pemilihan yang terjadi); dan pilihan stokastik (model stokastik berdasarkan sejarah tingkah laku).

\section{Karakteristik Belanja}

Karakterisik belanja dapat diartikan sebagai sifat khas seseorang dalam melakukan aktivitas belanja. Setiap rumah tangga memiliki karakteristik belanja yang berbeda-beda yang telah tumbuh dan menjadi suatu kebiasaan rumah tangga tersebut. Hal ini dapat dipengaruhi oleh banyak faktor. Menurut Bawa dan Ghosh (1999), kegiatan belanja kebutuhan harian adalah perilaku yang sering dipengaruhi oleh pendapatan, besar rumah tangga, suasana toko, dan keberadaan anak. Berdasarkan hal tersebut Lotoski dkk (2015) menyatakan bahwa, individu yang memiliki posisi sosial-ekonomi lebih rendah lebih memilih supermarket yang memiliki jarak yang dekat, jika dibandingkan dengan individu yang memiliki posisi sosial-ekonomi lebih tinggi.

Menurut Arredondo dkk (2006) dan Larson dkk (2006), teman belanja dapat mempengaruhi seseorang dalam melakukan aktivitas belanja kebutuhan sehari-hari yang saling berdampak satu sama lain, dimulai dari produk apa yang dibeli, pilihan lokasi belanja dan moda transportasi yang akan digunakan. Salah satu contoh dari teman belanja adalah anak. Keikutsertaan anak dalam berbelanja dapat mempengaruhi jumlah belanja hingga dua kali lipat dan ditemukan lebih banyak produk dari permintaan anaknya.

Karakteristik belanja lainnya yang dapat mempengaruhi pilihan lokasi belanja kebutuhan sehari-hari adalah dengan perencanaan belanja menggunakan iklan maupun promo. Berdasarkan Smith dan Casrky (1996), konsumen yang sering menggunakan iklan untuk merencanakan belanja mereka percaya bahwa praktik ini paling relevan dan berguna dalam hal menyimpan uang. Selanjutnya, penelitian telah menunjukkan bahwa ada kurangnya loyalitas terhadap toko spesifik (terutama selama atau setelah resesi) dan sejumlah konsumen yang signifikan berpindah toko untuk mengambil keuntungan dari potongan harga (Hampson dan McGoldrick, 2013; Food Marketing Institute, 2014).

Moda transportasi atau kendaraan yang digunakan untuk berpindah tempat juga mempengaruhi seseorang dalam menentukan pilihan lokasi belanja kebutuhan sehari-hari. Beberapa penelitian menunjukkan karakteristik sosial- 
ekonomi rumah tangga, lingkungan bangunan, dan atribut tingkat pelayanan mempengaruhi penggunaan angkutan barang dalam perjalanan belanja (Boerkamps dkk, 2000; Gonzales-Feliu dkk, 2010; Russo dan Comi, 2010; Miodonski dan Kawamura, 2012; Comi dan Nuzzolo, 2014).

Dapat disimpulkan berdasarkan tinjauan pustaka mengenai karakteristik belanja, penelitian ini akan menggunakan produk belanja, daftar belanja, waktu dan frekuensi belanja, lokasi belanja, dan moda transportasi belanja sebagai variable-variabel yang akan mewakili karakteristik belanja.

\section{Karakteristik Toko Penyedia Kebutuhan}

Selain karakteristik belanja seseorang, layanan yang ditawarkan oleh toko juga merupakan aspek utama yang dapat mempengaruhi pilihan lokasi belanja kebutuhan sehari-hari. Berdasarkan penelitian yang diadakan oleh Wang dan Lo (2005), dapat disimpulkan arti dari belanja kebutuhan sehari-hari. Pertama, belanja kebutuhan sehari-hari tidak hanya tentang mendapatkan produk (contohnya ikan dan daging), tapi bagaimana produk tersebut diproses dan disajikan dalam mode budaya tertentu (contohnya ikan hidup atau sisa tulang rusuk dipotong kedalam bentuk kubus). Kedua, belanja kebutuhan sehari-hari tidak hanya tentang mendapatkan barang yang tepat dalam daftar belanja, tetapi juga tentang mengekspresikan identitas individual dan menikmati keunikan budaya dan suasana sosial dari lingkunan belanja etnis tersebut. Belanja kebutuhan sehari-hari tidak hanya tentang mendapatkan barang yang tepat dalam daftar belanja, tetapi juga tentang mengekspresikan identitas individual dan menikmati keunikan budaya dan suasana sosial dari lingkunan belanja etnis tersebut (Goswami, 2008).

Perluasan penggunaan internet yang besar dan cepat menimbulkan penjualan secara daring yang menyebar. KirbyHawkins, Elena. (2016) Hal ini pun menjadi faktor yang dapat mempengaruhi pilihan lokasi belanja kebutuhan seharihari. Akan tetapi menurut Rotem-Mindali dan Weltevreden (2013), belanja secara daring untuk bahan makanan menunjukkan adanya perbedaan potensi konsumen jika dibandingkan dengan berbelanja produk secara langsung di toko. Berbeda dengan belanja untuk produk yang dapat dipilih, dikirim, dirasakan dan bahkan dikonsumsi secara daring, seperti buku, film dan musik.

Dapat disimpulkan berdasarkan tinjauan pustaka mengenai faktor layanan toko, penelitian ini akan menggunakan lokasi toko, harga produk, tingkat kenyamanan, aktivitas dan sarana tambahan, kesamaan etnis, kesamaan agama, dan berbelanja secara daring sebagai variabel-variabel yang akan mewakili karakteristik belanja.

\section{METODOLOGI PENELITIAN}

\section{Prosedur Penelitian}

Dalam penelitian ini digunakan metode kuantitatif dengan pendekatan deskriptif. Penelitian dilakukan menggunakan alat ukur kuesioner. Kuesioner disusun dengan menggunakan metode Likert dan pertanyaan terbuka. Likert dibuat dalam skala frekuensi dan skala kesetujuan. Scoring metode likert dapat dilihat pada Tabel 1.

Tabel 1. Scoring Metode Likert

\begin{tabular}{llc}
\hline & Skala Likert & Scoring \\
\hline \multirow{4}{*}{ Likert } & Sangat Tidak Setuju & 1 \\
Kesetujuan & Tidak Setuju & 2 \\
& Setuju & 3 \\
& Sangat Setuju & 4 \\
\hline \multirow{3}{*}{ Likert } & Jarang & 1 \\
Frekuensi & Kadang-Kadang & 2 \\
& Sering & 3 \\
& Sangat Sering & 4 \\
\hline
\end{tabular}

Subjek penelitian merupakan indivitu utama dalam rumah tangganya yang melakukan aktivitas belanja kebutuhan sehari-hari dan bertanggung jawab dalam menyediakan kebutuhan sehari-hari rumah tangganya. Lokasi penelitian yang digunakan dalam penelitian ini adalah hunian atau tempat tinggal di wilayah JABODETABEK (Jakarta, Bogor, Depok, Tangerang dan Bekasi). 
Target penelitian ini adalah mengumpulkan minimal 100 responden yang bertempat tinggal di wilayah Jabodetabek. Berdasarkan penelitian yang diadakan oleh Hartman Group pada tahun 2017, 76\% pelaku belanja kebutuhan seharihari adalah wanita. Atas dasar hal tersebut target responden dari kuisioner ini adalah $76 \%$ wanita dan $24 \%$ pria. Alur penelitian tertera dalam bentuk diagram seperti terlihat pada Gambar 1.

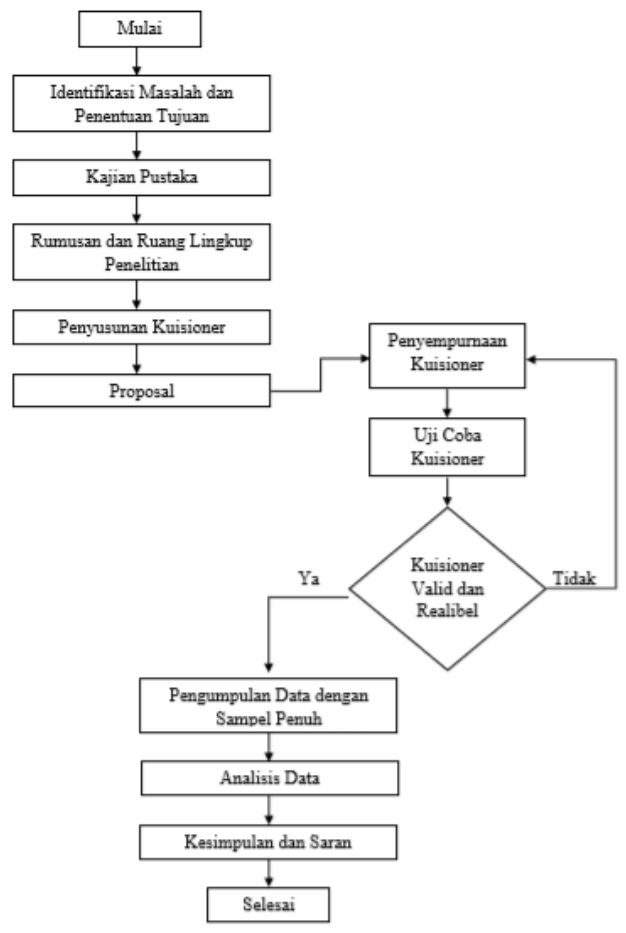

Gambar 1. Diagram Alur Penelitian

\section{Data Penelitian}

Data penelitian dibagi menjadi tiga bagian besar yaitu data umum, karakteristik belanja, dan karakteristik toko. Tiga bagian tersebut dispesifikasikan sebagai berikut:

1. Data Umum

- Jenis kelamin

- Usia

- Pendidikan terakhir

- Pekerjaan

- Etnis

- Agama

- Jumlah anggota rumah tangga

2. Karakteristik Belanja

- Jenis produk belanja

- Keberadaan daftar belanja

- Waktu dan frekuensi belanja

- Jarak lokasi belanja

- Pengaruh teman belanja

- Moda transportasi yang digunakan

3. Karakteristik Toko

- Lokasi toko

- Harga produk

- Tingkat kenyamanan

- Aktivitas dan sarana tambahan

- Kesamaan etnis atau suku

- Kesamaan Agama

- Layanan Belanja secara Online 


\section{Metode Analisis Data}

Tabel 3. Kelompok Aspek Faktor yang Mempengaruhi Pilihan Lokasi Belanja

\begin{tabular}{|c|c|c|c|}
\hline \multirow{2}{*}{ Indikator } & \multirow{2}{*}{ Rataan } & \multicolumn{2}{|c|}{ One Sample T-Test } \\
\hline & & $\alpha$ & Signifikan pada $\alpha \leq 0,05 ?$ \\
\hline Produk belanja & 3,14 & $<0,001$ & $\mathrm{Ya}$ \\
\hline Waktu belanja & 2,86 & $<0,001$ & Ya \\
\hline Keberadaan daftar belanja & 2,77 & $<0,001$ & $\mathrm{Ya}$ \\
\hline Moda transportasi & 2,83 & $<0,001$ & Ya \\
\hline Jarak lokasi toko dari rumah atau kantor & 2,97 & $<0,001$ & $\mathrm{Ya}$ \\
\hline Tingkat kenyamanan & 3,08 & $<0,001$ & Ya \\
\hline Berbelanja berbagai kebutuhan lainnya selain kebutuhan sehari-hari & 2,86 & $<0,001$ & Ya \\
\hline Keberadaan tempat makan di sekitar lokasi toko & 2,78 & $<0,001$ & Ya \\
\hline Keberadaan tempat hiburan (bioskop, game center) di sekitar lokasi toko & 2,29 & 0,004 & Ya \\
\hline Kesamaan etnis atau suku & 1,71 & $<0,001$ & Ya \\
\hline Kesamaan agama & 1,64 & $<0,001$ & $\mathrm{Ya}$ \\
\hline
\end{tabular}

Metode analisis data yang digunakan dalam penelitian ini adalah:

1. Uji Validitas menggunakan Pearson Method

2. Uji Reliabilitas menggunakan Nilai Cronbach's Alpha

3. Uji Hipotesis Selisih Rataan menggunakan One Sample T-Test

4. Analisis Korelasi Pearson

\section{ANALISIS DATA}

\section{Karakteristik Responden}

Setelah dilakukan pengumpulan data dengan sampel penuh didapatkan sebanyak 125 responden, 56 responden dari kuesioner langsung dan 69 responden dari kuesioner online.

\section{Pengolahan Data}

Dalam penelitian ini atribut dari data umum baik yang bersifat ordinal (pendidikan terakhir dan pengeluaran) maupun bersifat nominal (jenis kelamin, agama dan etnis atau suku) diberikan nilai berupa bilangan bulat positif mulai dari satu, sebagaimana ditampilkan pada Tabel 5.3. Dengan demikian untuk perhitungan korelasi terhadap data umum nilai tersebut yang akan dikorelasikan dengan variabel lainnya.

Dilakukan pengelompokan pertanyaan atau pengelompokan aspek penelitian berdasarkan pembahasan dan tipe pertanyaan. Tipe pertanyaan dibagi menjadi dua bagian, yaitu pertanyaan persepsi/opini (Bagian A) dan pertanyaan faktual (Bagian B). Pengelompokan aspek penelitian menghasilkan delapan belas buah kelompok aspek, dengan sembilan kelompok aspek persepsi/opini dan sembilan kelompok aspek faktual.

\section{Analisis Data menggunakan Uji One Sample T-Test}

Terlihat bahwa hampir semua aspek faktor yang mempengaruhi pilihan lokasi belanja memiliki nilai rataan lebih dari 2,5 yang mengindikasikan bahwa sebagian besar responden setuju dengan pernyataan yang telah disebutkan. Namun sebagian besar responden tidak setuju dengan pernyataan mengenai keberadaan tempat hiburan, kesaman etnis atau suku dan kesamaan agama sebagai faktor yang mempengaruhi pilihan lokasi belanja, terlihat dari nilai rataan yang kurang dari 2,5. Jenis produk belanja dan tingkat kenyamanan merupakan dua faktor yang berperan sangat penting yang dapat mempengaruhi pilihan lokasi belanja responden. Berdasarkan kolom hasil uji one sample t-test dapat disimpulkan bahwa hasil data memiliki perbedaan yang signifikan atau berarti dalam nilai rataan satu variabel. Hal ini menunjukkan konsistensi responden dalam menentukan faktor-faktor apa saja yang mempengaruhi pilihan lokasi belanja responden. 
Tabel 4. Jenis Produk Belanja

\begin{tabular}{|c|c|c|c|}
\hline \multirow{2}{*}{ Indikator } & \multirow{2}{*}{ Rataan } & \multicolumn{2}{|r|}{ One Sample T-Test } \\
\hline & & $\alpha$ & Signifikan pada $\alpha \leq 0,05 ?$ \\
\hline Produk Segar (sayuran, ikan, buah-buahan, daging merah) & 3,13 & $<0,001$ & Ya \\
\hline Rempah-rempah (bumbu dapur, bumbu jadi, sambal, kecap) & 2,80 & $<0,001$ & Ya \\
\hline Produk kering (produk yang diawetkan, makanan kaleng, makanan siap masak/instant) & 2,19 & $<0,001$ & Ya \\
\hline Makanan kecil (snack, biskuit, kue kering) & 2,42 & 0,279 & Tidak \\
\hline Pembersih rumah (sabun cuci piring, cairan pembersih lantai, sabun cuci pakaian) & 3,00 & $<0,001$ & Ya \\
\hline Perlengkapan mandi (sabun mandi, cairan pencuci rambut, deodorant) & 3,07 & $<0,001$ & Ya \\
\hline Kertas tisu & 2,89 & $<0,001$ & Ya \\
\hline Susu dan makanan bayi & 1,70 & $<0,001$ & Ya \\
\hline Kosmetik (cream wajah, wax rambut, body lotion) & 2,28 & 0,005 & Ya \\
\hline Obat-obatan & 2,14 & $<0,001$ & Ya \\
\hline Peralatan elektronik habis pakai (lampu, baterai) & 1,82 & $<0,001$ & Ya \\
\hline
\end{tabular}

Tabel 4. menunjukkan frekuensi jenis-jenis produk yang sering dibelanjakan oleh responden pada saat belanja kebutuhan sehari-hari. Produk segar, produk pembersih rumah dan produk perlengkapan mandi merupakan produk yang paling sering dibelanjakan. Hal tersebut ditunjukkan melalui nilai rataan yang cukup tinggi jika dibandingkan dengan produk lainnya. Produk susu dan makanan bayi serta produk peralatan elektronik habis pakai (lampu, baterai) merupakan produk yang paling jarang dibelanjakan. Didukung melalui kolom one sample t-test dapat dinyatakan bahwa seluruh nilai rataan dari jenis produk belanja memiliki perbedaan yang signifikan, kecuali produk makanan kecil.

Tabel 5. Kriteria Kenyamanan yang Mempengaruhi Pilihan Lokasi Belanja

\begin{tabular}{lccc}
\hline \multirow{2}{*}{ Indikator } & \multirow{2}{*}{ Rataan } & \multicolumn{2}{c}{ One Sample T-Test } \\
\cline { 3 - 4 } & & $\boldsymbol{\alpha}$ & Signifikan pada $\boldsymbol{\alpha} \leq \mathbf{0 , 0 5} ?$ \\
\hline Kualitas pelayanan pekerja & 3,07 & $<0,001$ & Ya \\
\hline Kebersihan & 3,17 & $<0,001$ & Ya \\
\hline Rambu atan papan penanda informasi produk dalam toko & 2,85 & $<0,001$ & Ya \\
\hline Keberadaan lahan parkir yang layak & 2,93 & $<0,001$ & Ya \\
\hline
\end{tabular}

Pada Tabel 5 terlihat bahwa kualitas pelayanan pekerja dan kebersihan toko merupakan dua variabel yang berperang penting sebagai kriteria kenyamanan toko yang mempengaruhi pilihan lokasi belanja responden.

Tabel 6. Moda Transportasi yang Digunakan untuk Kegiatan Sehari-hari

\begin{tabular}{lrrr} 
& \multirow{2}{*}{ Indikator } & Rataan & \multicolumn{2}{c}{ One Sample T-Test } \\
\cline { 3 - 4 } & & $\boldsymbol{\alpha}$ & Signifikan pada $\boldsymbol{\alpha} \leq \mathbf{0 , 0 5} ?$ \\
\hline Berjalan kaki & 1,99 & $<0,001$ & Ya \\
\hline Mobil & 2,29 & 0,033 & Ya \\
\hline Sepeda Motor & 2,23 & 0,011 & Ya \\
\hline Transportasi umum pribadi (Taksi) & 1,58 & $<0,001$ & Ya \\
\hline Transportasi umum (Bis, Angkot, Kereta) & 1,86 & $<0,001$ & Ya \\
\hline Layanan transportasi online (Gojek, Grab) & 2,70 & 0,033 & Ya \\
\hline
\end{tabular}

Berdasarkan Tabel 6 dapat disimpulkan bahwa sebagian besar responden sering menggunakan layanan transportasi online untuk kegiatan sehari-harinya.

Tabel 7. Moda Transportasi yang Digunakan untuk Berbelanja Kebutuhan Sehari-hari

\begin{tabular}{lccc}
\hline \multirow{2}{*}{ Indikator } & \multirow{2}{*}{ Rataan } & \multicolumn{2}{c}{ One Sample T-Test } \\
\cline { 3 - 4 } & & $\boldsymbol{\alpha}$ & Signifikan pada $\boldsymbol{\alpha} \leq \mathbf{0 , 0 5 ?}$ \\
\hline Berjalan kaki & 2,02 & $<0,001$ & Ya \\
\hline Mobil & 2,37 & 0,224 & Tidak \\
\hline Sepeda Motor & 2,25 & 0,017 & Ya \\
\hline Transportasi umum pribadi (Taksi) & 1,46 & $<0,001$ & Ya \\
\hline Transportasi umum (Bis, Angkot, Kereta) & 1,42 & $<0,001$ & Ya \\
\hline Layanan transportasi online (Gojek, Grab) & 2,08 & $<0,001$ & Ya \\
\hline
\end{tabular}

Berdasarkan Tabel 7 dapat disimpulkan bahwa sebagian besar responden cukup sering menggunakan moda transportasi mobil dan motor untuk berbelanja kebutuhan sehari-hari.

Membandingkan Tabel 6 dan Tabel 7 dapat dilihat adanya peningkatan nilai yang cukup signifikan pada indikator berjalan kaki, mengendarai mobil dan mengendarai sepeda motor serta adanya penurunan nilai yang cukup signifikan terjadi pada indikator transportasi umum. 


\section{Analisis Data Menggunakan Korelasi Pearson}

Korelasi dilakukan dengan menggunakan data variabel dari 18 kelompok aspek terhadap 7 jenis data umum. Pada kelompok aspek tertentu dilakukan analisis secara khusus dengan menggunakan nilai mean kelompok aspek. Hal ini dilakukan untuk menunjukkan hubungan kelompok aspek secara rata-rata dengan data umum responden. Kelompok aspek yang digunakan adalah kelompok aspek dengan jenis persepsi.

Tabel 8. Kelompok Aspek Faktor yang Mempengaruhi Pilihan Lokasi Belanja vs Jenis Kelamin

\begin{tabular}{|c|c|c|c|}
\hline Kelompok Aspek Faktor yang Mempengaruhi Pilihan Lokasi Belanja & $\begin{array}{c}\text { Koefisien } \\
\text { Korelasi (R) }\end{array}$ & $\boldsymbol{\alpha}$ & Signifikan pada $\alpha \leq 0,05$ ? \\
\hline Produk belanja & $-0,253$ & 0,002 & Ya \\
\hline Jam belanja & 0,025 & 0,389 & Tidak \\
\hline Keberadaan daftar belanja & 0,077 & 0,198 & Tidak \\
\hline Moda transportasi & 0,670 & 0,229 & Tidak \\
\hline Jarak lokasi belanja & $-0,120$ & 0,091 & Tidak \\
\hline Tingkat kenyamanan & 0,057 & 0,266 & Tidak \\
\hline Berbelanja berbagai kebutuhan lainnya selain kebutuhan sehari-hari & $-0,110$ & 0,111 & Tidak \\
\hline Keberadaan tempat makan di sekitar lokasi toko & $-0,073$ & 0,209 & Tidak \\
\hline Keberadaan tempat hiburan (bioskop, game center) & 0,052 & 0,284 & Tidak \\
\hline Kesamaan etnis atau suku & $-0,330$ & $-0,357$ & Tidak \\
\hline Kesamaan agama & $-0,014$ & 0,439 & Tidak \\
\hline Mean aspek faktor yang mempengaruhi pilihan lokasi belanja & $-0,056$ & 0,266 & Tidak \\
\hline
\end{tabular}

Berdasarkan Tabel 8 dapat disimpulkan bahwa jika dibandingkan dengan laki-laki, pilihan lokasi belanja pada responden wanita lebih dipengaruhi oleh produk belanja.

\section{KESIMPULAN}

Berdasarkan penelitian yang telah dilakukan dapat disimpulkan sebagai berikut:

1. Karakteristik belanja responden (jenis produk, jam belanja, teman belanja, daftar belanja, jarak lokasi belanja, dan moda transportasi belanja) mempengaruhi pilihan lokasi belanja kebutuhan sehari-hari responden. Jenis produk belanja merupakan salah satu karakteristik belanja yang paling mempengaruhi pilihan lokasi belanja responden. Karakteristik belanja responden sebagian besar dipengaruhi oleh latar belakang responden antara lain pendidikan terakhir responden, jenis kelamin responden, agama responden, besar pengeluaran responden dan jumlah anggota rumah tangga responden.

2. Karakteristik toko penyedia kebutuhan sehari-hari (tingkat kenyamanan, produk kebutuhan lainnya, fasilitas tempat makan, fasilitas tempat hiburan, kesamaan etnis atau suku, dan kesamaan agama) tidak sepenuhnya mempengaruhi pilihan lokasi belanja kebutuhan sehari-hari responden. Tingkat kenyamanan, keberadaan produk kebutuhan lainnya dan fasilitas tempat makan merupakan tiga karakteristik toko yang paling mempengaruhi pilihan lokasi belanja responden. Ketiga karakteristik toko tersebut sebagian besar dipengaruhi oleh latar belakang responden seperti usia dan pendidikan terakhir responden.

3. Variabel yang paling berperan besar dalam pemilihan lokasi belanja kebutuhan sehari-hari responden adalah karakteristik perjalanan belanja responden. Jenis produk yang akan dibelanjakan berperan penting dalam karakteristik perjalanan belanja responden. Pemilihan lokasi belanja atas dasar jenis produk yang akan dibelanjakan cenderung dilakukan oleh wanita dibandingkan dengan pria.

\section{SARAN}

\section{Saran Pemanfaatan Penelitian}

Berdasarkan penelitian dan penarikan kesimpulan yang telah dilakukan dapat direkomendasikan saran terhadap pemanfaatan penelitian ini, yakni:

1. Penelitian ini dapat digunakan sebagai dasar pertimbangan desain transportasi terpadu pada suatu wilayah dalam rangka memperbaiki maupun merencanakan lalu lintas.

2. Adanya perbedaan moda transportasi yang digunakan saat kebutuhan sehari-hari dengan moda transportasi yang digunakan saat berbelanja menunjukkan adanya ketidakpuasan masyarakat terhadap sarana transportasi yang ada. Atas dasar tersebut penulis menyarankan untuk memperbaiki desain sarana transportasi umum, sehingga dapat melayanani transportasi orang dan barang dengan nyaman. Salah satu hal yang dapat dilakukan adalah dengan menyediakan ruang khusus barang yang cukup besar pada sarana transportasi.

3. Masyarakat cenderung berbelanja menggunakan moda transportasi seperti mobil, sepeda motor maupun layanan transportasi umum pribadi seperti taksi. Hal ini menunjukkan bahwa responden melakukan aktivitas belanja 
dengan berusaha untuk meminimalkan adanya keperluan untuk berpindah tempat atau melakukan transit ditengah perjalanan. Dengan memperbanyak rute layanan transportasi umum di kawasan perbelanjaan dapat mempermudah pergerakan atau akses masyarakat untuk memenuhi perjalanan belanja.

\section{Saran terhadap Penelitian Selanjutnya}

Berdasarkan penelitian yang sudah dilakukan dapat direkomendasikan saran terhadap penelitian selanjutnya, yakni:

1. Memusatkan perhatian terhadap variabel-variabel yang dibutuhkan saja sehingga menghindari kuesioner yang terlalu panjang. Hal tersebut dapat menyebabkan responden merasa terbebani saat mengisi kuesioner.

2. Meneliti secara khusus hubungan antara satu kelompok variabel dengan kelompok variabel lainnya sehingga mendapatkan hasil penelitian yang lebih beragam.

3. Meneliti secara khusus situasi ketika perjalanan belanja kebutuhan sehari-hari menjadi bagian dari Multipurpose Trips atau perjalanan dengan banyak tujuan.

\section{DAFTAR PUSTAKA}

Arredondo, E. M., Elder, J. P., Ayala, G. X., Campbell, N., Baquero, B. dan Duerksen, S. (2006). "Is Parenting Style Related to Children's Healthy Eating and Physical Activity in Latino Families?". Health Education Research, 21, 862-871. doi:10.1093/her/ cyl110.

Bawa, K. dan Ghosh, A. (1999). “A Model of Household Grocery Shopping Behavior”. Marketing Letters, 10, 149160.

Boerkamps, J.H., van Binsbergen, A.J., Bovy, P.H.L. (2000). "Modeling Behavioural Aspects of Urban Freight Movement in Supply Chains". Transportation Research Record, 1725,.17-25.

Goswami, Paromita dan Mishra, Mridula S. (2008). Would Indian Consumers Move From Kirana Stores to Organized Retailers When Shopping for Groceries?". Asia Pacific Journal of Marketing and Logistics. DOI $10.1108 / 135558509101926281$.

Gonzales-Feliu, J., Toilier, F., Routhier, J.L. (2010). "End Consumer Goods Movement Generation in French Medium Urban Areas". The Sixth International Conference on City Logistics. Elsevier Ltd, 1877-0428.

Guy, C.M., Wringley, N., (1981). A Long-Term Grocery Shopping Diary Survey in Cardiff. Social Science Research Council.

Hampson, D.P., McGoldrick, P.J. (2013). “A Typology of Adaptive Shopping Patterns in Recession”. Journal of Business Research, 66(7), 831-838.

Hartman Group National Syndicated Research. (2018). Food Shopping in America 2017 Report Overview. Amerika: Hartman Group.

Kirby-Hawkins, E. (2016). Designing a Location Model for Face to Face and On-Line Retailing for the UK Grocery Market. ProQuest Dissertations Publishing, 10662053.

Larson, N. I., Story, M., Eisenberg, M. E. dan Neumark-Sztainer, D. (2006). "Food Preparation and Purchasing Roles Among Adolescents: Associations with Sociodemographic Characteristics and Diet Quality". Journal of the American Dietetic Association, 106, 211-218. doi:10.1016/j.jada.2005.10.029.

Lotoski, L.C., Engler-Stringer, R., Muhajarine, N. (2015). Cross-Sectional Analysis of a Community-Based Cooperative Grocery Store Intervention In Saskatoon, Canada. Canadian Journal of Public Health, 106(3), 147-153

Rotem-Mindali, O., Weltevreden, J.W.J. (2013). "Transport Effect of E-Commerce: What Can Be Learned After Years Of Research?". Transportation, 40, 867-885.

Routhier, J.L., Traisnel, J.P., Gonzales-Felius, J., Henriot, F., \& Raux, C. (2009). ETHEL-II. Rapport final. (dikutip pada Sun, Y.L., TARIGAN, A., Waygood, A., Wang, D.H., 2017. Diversity in Diversification: an Analysis of Shopping Trips in Six-Week Travel Diary Data. Journal of Zhejiang University-SCIENCE A (Applied Physics \& Engineering), ISSN 1862-1775 (Online)).

Smith, M.F., Carsky, M.L. (1996). "Grocery Shopping Behaviour: a Comparison of Involved and Uninvolved Consumers". Journal of Retailing and Consumer Services, Vol. 3 No. 2, pp. 73-80. 